\title{
Risk Tolerance and Satisfaction Level of Mutual Fund Retail Investors
}

\author{
Dr. Siby Joseph K, Associate Professor, MBA Dept; (BIMS) St. Berchmans College, \\ Changanacherry, Kottayam Dist. Kerala.sibyjoseph_k@yahoo.co.in \\ Dr. M. A Joseph, Professor \& HOD, Dept. of Commerce and Management Studies, \\ University of Calicut. Kerala. jsphma@gmail.com
}

\begin{abstract}
The retail investors in India are characterized by an affinity to avoid risk and they lack the mental readiness to absorb the shocks of the volatile capital market. Hence, to attract the surplus funds possessed by the retail investors into the capital market, intermediaries like mutual funds are required. Though apparently mutual funds were intended to cater to the needs of the retail investor, the stock market has not won investors' confidence to attract a growing share of household's financial savings. Today, more players are entering into the market and a naïve investor is unable to deploy the investment in the right direction. The study analyse the retail investors financial decision in terms of investing their savings in the capital market through mutual fund investment. The study found that, investor's with moderate risk tolerance level prefer to invest in mutual funds and return, marketability and liquidity are the most satisfying factors investor they look on.
\end{abstract}

Keywords: Demographic factors, Mutual Funds (MFs), Risk Tolerance, Satisfaction Level

\section{INTRODUCTION}

Making wise financial investments is one of the most important and challenging decisions faced by retail investors. One way to maintain and build wealth is to invest in the capital market. Retail investors are more comfortable in investing in a good representation of the capital market, but unfortunately they are unfamiliar with risk and diversification, thus making them exposed to the fluctuations within the market.

Mutual Fund has become an important portal for retail investors as it offers the advantage of portfolio diversification, professional management at low cost and high level of operational transparency. Innovations in information technology and increased financial disclosure are creating an investor friendly environment. Meanwhile with the increasing number of funds, the task of picking up the right funds that match ones investment objective is challenging for the retail investors.

Individual investors are generally constrained by inadequate knowledge, non-availability of information, lack of investment skill, etc. that effect the foundation of investment perception as well as the investment activities. Their decision making on investment choices often relies on observable socio-demographic variables. An understanding of investor risk behaviour is an important task for asset managers in order to be successful in the battle of fund flows. The research paper seeks to answer the how the demographic variables influence the risk tolerance and satisfaction level of investors.

\section{RESEARCH OBJECTIVES}

The objective of the study was to analyse the following:

a. To find out whether there is any association between demographic and risk tolerance level of mutual fund investors.

b. To find out whether there is any association between demographic and level of satisfaction among mutual fund investors.

c. To examine the satisfaction level of respondents with respect to various demographic factors of mutual fund investors.

d. To determine whether there is any significant difference between the risk tolerance and satisfaction level of the mutual fund investors.

\section{HYPOTHESIS}

The study is based on the formulation of the following null hypothesis:

$\mathrm{H}_{01}$ : There is no association between demographic to risk tolerance level. 
$\mathrm{H}_{02}$ : There is no association between demographic variables to level of satisfaction.

$\mathrm{H}_{03}$ : There is no significant difference among risk tolerance level of mutual fund investors and their satisfaction level.

\section{LITERATURE REVIEW}

One of the pillars concepts for investments and decision making is the concept of risk. In the traditional theories risk is determined using both the deviations from the average return and the probability of those deviations. An investor attitude toward risk could be characterized as risk-aversion, risk seeking (risk-tolerance, risk-taking, risk loving) or risk neutrality. This attitude is influenced by several factors: the competition and collaboration between the cognitive and affective system (Lowenstein et al. 2001) ${ }^{1}$, demographic factors (Byrnes et al. 1999) ${ }^{2}$ and the temporal perspective (Jaggia and Thosar $(2000)^{3}$

Wallach and Kogan $(1961)^{4}$ are generally considered to be the first researchers to study the relationship between risk tolerance and age. Their early experimental research used choice dilemmas which indicated that elder individuals were less risk tolerant than younger individuals. There also is a "prevalent belief in our culture that men do take greater risks than women" Slovic (1966) ${ }^{5}$ " which has generated a consensus among investment managers that gender is an effective differentiating and classifying factor".

Baker and Hasle (1974) $)^{6}$ "the balancing of risk and return represents the classic dilemma faced by investors." Cohn, Lewellen et.al (1975) "found risky asset fraction of the portfolio to be positively correlated with income and age and negatively correlated with marital status". Friend and Blume (1975) ${ }^{8}$ observe that" an individual's risk tolerance can be inferred from the asset allocation decision by calculating the percentage of a person's assets invested in risky securities. The extent of an investor's ability to tolerate these uncertainties of return is referred as risk tolerance level of an investor".

Morin and Suarez (1983) "found evidence of increasing risk aversion with age although the households appear to become less risk averse as their wealth increases". Risk tolerance tends to be subjective rather than objective. This approach was extended by Bellante and Saba $(1986)^{10}$ Siegel and Hoban $(1991)^{11}$ Riley and Chow $(1992)^{12}$.

LeBaron, Farrelly and Guha (1989) ${ }^{13}$ and Schooley and Worden (1996) " "obtain a measure of risk tolerance by survey. It is amply documented that risk is a factor that shapes individuals' decisions, including financial and investment decisions", Lipe ( 1998) ${ }^{15}$; and Yang and Qiu $2005)^{16}$. It is risk that determines the rate of return that the investors are likely to receive.
Viscusi (1992) ${ }^{17}$ "infers risk tolerance from a willingness to undertake risky endeavours in other areas of life. Many things other than financial risk tolerance affect willingness to engage in other sorts of risky behaviour". Horvath and Zuckerman (1993) 18 "suggested that one's biological, demographic and socioeconomic characteristics together with his/her psychological makeup affects one's risk tolerance level". Roszkowski, Snelbecker, and Leimberg $(1993)^{19}$ "considered gender as an important investor risktolerance classification factor because more men than women tend to fit the personality trait called "thrill seeker" or "sensation seeker" .It is assumed that single individuals have less to lose by accepting greater risk compared to married individuals who often have responsibilities for themselves and dependents. Second, it is assumed that married individuals are more susceptible to social risk, which is defined as the potential loss of esteem in the eyes of colleagues and peers, if an investment choice leads to increased risk of loss". Yoo (1994) ${ }^{20}$ "found that the change in the risky asset holdings were not uniform. He found individuals to increase their investments in risky assets throughout their working life time, and decrease their risk exposure once they retire".

Mittra $(1995)^{21 "}$ discussed factors that were related to individuals risk tolerance, which included years until retirement, knowledge sophistication, income and net worth". Haliassos and Bertaut (1995) $)^{22}$ "determined that education was an important factor in overcoming the barriers to stockholding, which included an initial risk of loss associated with equities". Sung and Hanna (1996a) ${ }^{23}$, $(1996 b)^{24}$ "studied the effects of financial and demographics variables on risk tolerance were estimated for households with an employed respondents. Logistic regression analysis showed that female headed households were less likely to be risk tolerant than other wise similar households with a male head or a married couple. Differences in risk tolerance by gender, marital status, ethnic group, education could be due to differences in understanding of the nature of risk". Sung and Hanna concluded that single females were less likely to take financial risks than single males and married individuals. Malkie (1996) ${ }^{25}$ " suggested that an individual's risk tolerance is related to his/her household situation, lifecycle stage and subjective factors".

Canner, Mankiw and Weil (1997) "suggest that Wall Street financial planners often recommend a different mix of financial assets for highly risk tolerant clients than for more risk adverse individuals. John E. Grable $(1997)^{27}$ "study was designed to determine whether the variables gender, age, marital status, occupation, self-employment, income, race, and education could be used individually or in combination to both differentiate among levels of investor risk tolerance and classify individuals into risk-tolerance categories. Two demographic characteristics were 
determined to be the most effective in differentiating among and classifying respondents into risk-tolerance categories. Classes of risk tolerance differed most widely on respondents' educational level and gender. Educational level of respondents was determined to be the most significant optimizing factor. It also was concluded that demographic characteristics provide only a starting point in assessing investor risk tolerance".

According to Olsen $(1998)^{28}$ "most people consider themselves to be risk-avoiders rather than risk-takers. People will make decisions in which they are willing to accept a certain small return rather than a larger, but uncertain profit from their financial decisions. The function of a measure of risk tolerance should be to differentiate people on the basis of the level of risk that they are willing to accept. Such a test can also be used to measure the risk tolerance of the same person over time. That is, attitudes like risk tolerance are likely to change over time as people experience the positive and negative outcomes of their previous investment decisions, changes with age to their family or work lives, and changes in the performance of markets".

Demographic factors as gender or age induce important shifting in risk attitude. Byrnes et al. (1999) ${ }^{29}$ "validates the assumption of a higher propensity for taking risk in male investors and found that this tendency of the gender gap to decrease with age. Other important factor is represented by the temporal perspective. The investors' confidence in their prospect for success decreases as they come closer to the investment liquidation date so usually the risk assessment is more conservative with shorter temporal distance that in longer term investments" .In a recent variant of this approach, Bajtelsmit, Bernasek and Jianakoplos (1999) ${ }^{30}$ "presents a version of the Capital Asset Pricing Model that allows individuals to allocate their funds between risky assets, a risk-free asset. Consequently investors with high human capital investments hold larger fractions of their wealth in risky assets".

Govind Hariharan, Kenneth S. Chapman, and Dale L. Domian $(2000)^{31}$ use a large individual level data set to isolate the effects of risk tolerance on portfolio composition. "They tested and confirm two predictions of the Capital Asset Pricing Model- (i) increased risk tolerance reduce an individual's propensity to purchase risk-free assets and (ii) higher risk tolerance does not affect the composition of an individual's portfolio of risky assets". The risk tolerant investors nearing retirement do not reduce their bond allocations in order to buy more stock. Jaggia and Thosar (2000) ${ }^{32}$ argue that "risk perception is not only a function of age but also of temporal distance between the initial investment point and the cash-out point typically represented by the individuals retirement."
Barber and Odean (2001) $)^{33}$ "have shown that overconfidence may result in more trading, but no better returns. Lack of confidence may however influence motivation to learn more about the stock market and in that way be negative for many women". On the other hand recent literature in Behavioural Finance argues that overconfidence leads to higher trading volume. This idea was first presented by Barber and Odean who claim that gender is a good proxy for overconfidence (overconfidence among men is higher than among women) and find that men trade more than women.

Dwyer, Gilkeson and List (2002) ${ }^{34}$ using data from a national survey of nearly 2000 mutual fund investors examined, whether the risk taking behaviour of mutual fund investors is correlated to gender. The findings revealed that "women exhibit less risk taking than men and the impact of risk taking is significantly weakened when investor's knowledge is controlled in regression equation". Dulebohn, James H (2002) $)^{35}$ "presents the result of an investigation of the determinants of investment behaviour in employee sponsored retirement plans. He examined the significance of demographic and attitudinal variables on employees risk behaviour in selecting among investment allocation options. The results identified primary causes of risky investment behaviour including income, age, other retirement plan participation, self- efficacy, knowledge of investment and general risk propensity".

Kenneth A. Froot, Paul G. J. and O'Connell (2003) "proposed a methodology for measuring investor confidence by decomposing investor demand for international assets. This was based on an examination of the cross section of international portfolio holdings and flows of international institutional investors over time. The risk tolerance component turns out to account for a substantial portion of variation in portfolio holdings and a smaller but meaningful amount of variation in equity returns. In addition, it appears to be informative about future returns". Rajarajan V $\left(1997^{37}, 1998^{38}, 2000^{39}\right.$ and $2003^{40}$ ) classified investors on the basis of their demographics. "He has also brought out the investors' characteristics on the basis of their investment size. He found that the percentage of risky assets to total financial investments had declined as the investor moves up through various stages in life cycle. Also investors' lifestyle based characteristics have been identified. The findings of many of the studies are verified. The role of uncertainty and the lack of knowledge about the return on investment avenues are important component of any investment".

According to Frieder (2004) $)^{41}$ " illustrate that for many investors, investing constitutes more than simply weighting the risk and returns of various investment assets. Being aware of the many considerations and needs beyond risk and return that influence investors' behaviour, it is 
surprising that finance journals are mostly confined to the utilitarian benefits of low risk and high expected returns".

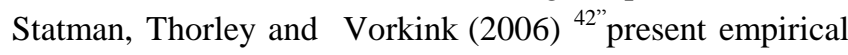
evidence for the US market and argue that trading volume is higher after high returns, as investment success increases the degree of overconfidence. This finding is consistent with the hypothesis that a higher degree of overconfidence leads to higher trading volume as long as we accept that high past returns are positively correlated with overconfidence".

Glaser and Weber (2007) "confirm higher trading propensity for overconfident investors when they identify overconfident investors as those who think they are above average in terms of investment skills or past performance. The same conclusion doesn't hold when the authors use measures of mis calibration as proxies for overconfidence". Jasim Y. Al-Ajmi (2008) ${ }^{44}$ study presents new evidence on the determinants of risk tolerance of individual investors in Bahrain. "The findings indicate that as investors, men have high propensity towards risk tolerance than women. Investors with better level of education and wealth are more likely to seek risk than less educated and less wealthy ones. The study also reports those investors' risk tolerance declines when they have more financial commitments as well as when they are approaching towards their retirement age or are retired. That is, the effect of investor's age on risk tolerance is complex, in contrast to results reported elsewhere. Bahrainis are also found to be less risk tolerant than non-Bahrainis".

Prabakaran and Jayabal (2009) ${ }^{45}$ quantified the risk tolerance of mutual fund investors. Study identifies the socio economic variables and correlates the same with risk tolerance. Empirically it has been proved mutual fund investors are from low and moderate risk tolerant groups. Syed Tabassum Sultana $(2010)^{46}$ "confirms the earlier findings with regard to the relationship between gender and age, the risk tolerance level of individual investors. The study has important implications for investment managers as it has come out with certain interesting facets of an individual investor. The individual investor still prefers to invest in financial products which give risk free returns".

Rui Yaoa, Deanna L. Sharpe, Feifei Wangc $(2011)^{47}$ "study uses an analytical method to separate effects on financial risk tolerance. Results supported the hypothesis that, age has a negative effect on the willingness to take financial risks. As people age they are likely to accumulate investment experience which would positively influence the willingness to accept risk. Knowledge of and experience with investments may also influence difference in the perception of financial risks". Ebrahim Kunju Sulaiman $(2012)^{48}$ "reports the results of the study that was designed to examine the association/relationship between the risk tolerance of individual investors and their demographic features. Most of the anticipated relationship between financial risk tolerance and each of the demographic features from the literature were found to be relevant".

Rahmawati et. al. $(2015)^{49}$ studied the determinants of the risk tolerance of individual investors with an objective to evaluate various factors which were responsible related to financial risk tolerance and affects investment decisions. They have taken gender, education, age, wealth as independent factor. They found that all these factors have significant impact on financial risk tolerance of investors and it affects investment decision also. Chattopadhyay and Dasgupta (2015) ${ }^{50}$ studied the demographic and socio economic impact on risk attitude of Indian investors. The main aim of their study was to investigate the role of various factors like age, gender, number of dependents, marital status, income, employment, educations, saving patterns, investment amount, monetary planning and returns on risk tolerance of investors. They found a significant relationship of age, gender, marital status and income of investors with financial risk tolerance. They concluded that age was an important factor and as it increases investors tend to take positions in less risky asset while income as other factors has same reason that if income of any investors increases the risk taking ability also increases.

Chavali and Mohanraj (2016) ${ }^{51}$ investigated the impact of risk tolerance on investment decision by considering scale developed by Grable and Lytton. They found that investors are by default risk averse in nature and do not want to take risk and always try to avoid risk while doing investment. The risk perception of investors depends on various demographic characteristics like age, gender and income etc.

\section{RESEARCH METHODOLOGY}

The population for the research study was the mutual fund retail investors of Kerala. The sampling unit of this survey is an individual, who is technically called as a 'retail investor' who has invested in mutual funds during the period of study. For the research study, Kerala state was divided into three zones viz: South, Central and Northern zones. To analyse the geographical distribution of unit holders, the study was focused on Corporations, Municipality and Panchayath from each of these three zones. Retail Investors of various Asset Management Companies and clients of various depository participants, and banks from each zone constituted the source list.

To determine the sample size accurately, especially a study like this where there is no reliable source to determine the correct number of mutual fund investors in Kerala, the researcher used the power analysis based on the pilot study with $5 \%$ level significance ( $\mathrm{p}$ value) and $90 \%$ power to determine the sample size. The maximum required sample size turns to be 442 . The collection of data was based on 
multistage random sampling (geographical distribution of investors). A population sample survey among investors was collected from three zones. As the AUM by Geography - Consolidated data for MF Industry in three major Corporations of Kerala as on 31-Mar-2013 is less than $1 \%$ (Cochin $0.42 \%$, Trivandrum $0.15 \%$ and Calicut $0.05 \%$ ), it was evident that central Kerala has got more than double the size of mutual fund investors. Accordingly 150 questionnaires were distributed in north and south zone and 300 questionnaires were distributed in central zone. After editing of questionnaire for completion, accuracy and consistency the researcher was left out with 472 questionnaires

\section{Method for Data Collection}

The primary data were collected using survey method. The methodology adopted was through questionnaire method. Interview with AMC, Brokers and Experts were also carried out to gain more insight to the issue. The purpose of the survey was to understand the behavioural aspects of individual investors.

\section{RESULTS AND DISCUSSION}

The researcher tries to categorize the retail investor's risk perception and satisfaction level towards mutual fund investments by identifying various tolerance level based on demographic factors so as to unveil some extremely valuable information to support financial decision making of mutual funds. The study divided the respondents based on high, moderate and less risk tolerance. Their risk attitude was mostly influenced by demographic factors. Chi- square test was used to find the association between risk tolerance and demographic factors and one way ANOVA was calculated to find out whether there is any significance difference among the risk tolerance level of mutual fund investors and their satisfaction level.

\section{6a. Chi-Square-Demographic to Risk Tolerance Level}

The respondents were asked to mark their risk tolerance level on a five point scale and the score were tabulated based on three criterions viz; high, moderate and low risk tolerance. They were classified into high risk tolerance group if the score were five and four, three for moderate risk tolerance and two and one scores were classified under less risk tolerance investors.

Table 1 No. of Respondents to Risk Tolerance Level

\begin{tabular}{|c|c|c|c|c|}
\hline Risk Tolerance & Frequency & $\begin{array}{c}\text { Per } \\
\text { cent }\end{array}$ & $\begin{array}{c}\text { Valid } \\
\text { Percent }\end{array}$ & $\begin{array}{c}\text { Cumulative } \\
\text { Percent }\end{array}$ \\
\hline High risk tolerance & 100 & 21.19 & 21.19 & 21.19 \\
\hline $\begin{array}{c}\text { Moderate risk } \\
\text { tolerance }\end{array}$ & 208 & 44.07 & 44.07 & 65.26 \\
\hline Less risk tolerance & 164 & 34.74 & 34.74 & 100.0 \\
\hline Total & 472 & 100.0 & 100.0 & \\
\hline
\end{tabular}

Source: Primary Data
Of the total respondents $21.19 \%$ of mutual fund investors have high risk tolerance and $44.07 \%$ had moderate risk tolerance.

Table 2 Chi-Square - Demographic to Risk Tolerance Level

\begin{tabular}{|c|c|c|c|c|}
\hline Demographic Variable & $\begin{array}{c}\text { Chi- } \\
\text { Square }\end{array}$ & df & p value & Conclusion \\
\hline Gender & 0.121 & 2 & 0.941 & $\begin{array}{c}\text { Non- } \\
\text { Significant }\end{array}$ \\
\hline Age & 12.734 & 6 & 0.047 & Significant \\
\hline $\begin{array}{c}\text { Educational } \\
\text { Qualification }\end{array}$ & 3.9 & 4 & 0.42 & $\begin{array}{c}\text { Non- } \\
\text { Significant }\end{array}$ \\
\hline Area of Residence & 2.62 & 4 & 0.623 & $\begin{array}{c}\text { Non- } \\
\text { Significant }\end{array}$ \\
\hline Zone & 5.529 & 4 & 0.237 & $\begin{array}{c}\text { Non- } \\
\text { Significant }\end{array}$ \\
\hline Occupation & 0.924 & 2 & 0.63 & $\begin{array}{c}\text { Non- } \\
\text { Significant }\end{array}$ \\
\hline Annual Income & 9.046 & 6 & 0.171 & $\begin{array}{c}\text { Non- } \\
\text { Significant }\end{array}$ \\
\hline Annual Saving & 8.154 & 8 & 0.419 & $\begin{array}{c}\text { Non- } \\
\text { Significant }\end{array}$ \\
\hline
\end{tabular}

Source: Primary Data Significant at 0.05 levels

Ho: There is no association between demographic variables (gender, age, and educational qualification, area of residence, zone, occupation, annual income, and annual savings) to risk tolerance level.

Ha: There is association between demographic variables (gender, age, educational qualification, area of residence, zone, occupation, annual income, and annual savings) to risk tolerance level.

The Pearson chi square test was used to test the significance of the hypothesis. Among the various demographic variables, only in the case of age, the significance value was less than .05. Hence the null hypothesis is rejected in the case of age and concluded that, there is only association between the demographic variables namely age, and risk tolerance level.

\section{6b. Satisfaction Level of Mutual Fund Investors}

The respondents were asked to mark their level of satisfaction on a five point scale and the score were tabulated based on three criterions viz; satisfied, moderately satisfied and dissatisfied. They were classified into satisfied group if the score were five and four, three for moderately satisfied and two and one scores were classified under dissatisfied investors.

Table 3 Satisfaction Level

\begin{tabular}{|c|c|c|}
\hline Satisfaction Level & Frequency & Per cent \\
\hline Dissatisfied & 40 & 8.5 \\
\hline Moderately Satisfied & 386 & 81.8 \\
\hline Satisfied & 46 & 9.7 \\
\hline Total & 472 & 100 \\
\hline
\end{tabular}

Source: Primary Data

Of the total respondents, $82 \%$ were moderately satisfied with mutual fund as an investment avenue. 


\section{Satisfaction Level based on Demographics}

The study also intends to examine the satisfaction level of respondents with respect to various demographic factors of mutual fund investors.

Ho: There is no association between demographic variables (gender, age, educational qualification, area of residence, zone, occupation, annual income, and annual savings) to level of satisfaction.

Ha: There is association between demographic variables (gender, age, educational qualification, area of residence, zone, occupation, annual income, and annual savings) to level of satisfaction

Table 4 Chi-Square of Satisfaction based on Demographics

\begin{tabular}{|c|c|c|c|c|}
\hline Demographic Variable & $\begin{array}{l}\text { Chi- } \\
\text { Square }\end{array}$ & $\mathrm{df}$ & $\mathrm{p}$ value & Conclusion \\
\hline Gender & 1.427 & 2 & 0.49 & $\begin{array}{c}\text { Non- } \\
\text { Significant } \\
\end{array}$ \\
\hline Age & 14.623 & 4 & 0.006 & Significant \\
\hline $\begin{array}{c}\text { Educational } \\
\text { Qualification }\end{array}$ & 4.33 & 2 & 0.115 & $\begin{array}{c}\text { Non- } \\
\text { Significant }\end{array}$ \\
\hline Area of Residence & 2.182 & 4 & 0.702 & $\begin{array}{c}\text { Non- } \\
\text { Significant }\end{array}$ \\
\hline Zone & 12.524 & 4 & 0.014 & Significant \\
\hline Occupation & 5.721 & 2 & 0.057 & $\begin{array}{c}\text { Non- } \\
\text { Significant }\end{array}$ \\
\hline Annual Income & 7.167 & 4 & 0.127 & $\begin{array}{c}\text { Non- } \\
\text { Significant } \\
\end{array}$ \\
\hline Annual Saving & 4.356 & 6 & 0.629 & $\begin{array}{c}\text { Non- } \\
\text { Significant }\end{array}$ \\
\hline
\end{tabular}

Source: Primary Data Significant at 0.05 levels

The Pearson chi square test was used to test the significance of the hypothesis. The significance values in the case of demographic variables namely age and zone are less than .05 . Hence the null hypothesis is rejected in the case of age and zone. It can be concluded that, there is association between the demographic variables namely age, and zone to level of satisfaction.

From the table (model fit) all the fit were found to be within the limit, indicating the suitability of CFA.

Table 5 Model Fit Indices for CFA

\begin{tabular}{|c|c|c|c|c|c|c|c|c|c|c|c|}
\hline & $\chi^{2}$ & DF & P & $\begin{array}{c}\text { Nor } \\
\text { med } \chi^{2}\end{array}$ & GFI & AGFI & NFI & TLI & CFI & RMR & $\begin{array}{c}\text { RMS } \\
\text { EA }\end{array}$ \\
\hline $\begin{array}{l}\text { Reco } \\
\text { mme } \\
\text { nded }\end{array}$ & & & $>0.05$ & $<3$ & $>0.90$ & $>0.90$ & $>0.90$ & $>0.90$ & $>0.90$ & $<1$ & $<0.5$ \\
\hline & 16.919 & 16 & .391 & 1.057 & 0.988 & 0.974 & 0.973 & 0.997 & 0.998 & 0.080 & 0.013 \\
\hline
\end{tabular}

Source: Primary Data

Fig: 1 The Regression Coefficients showing Satisfaction

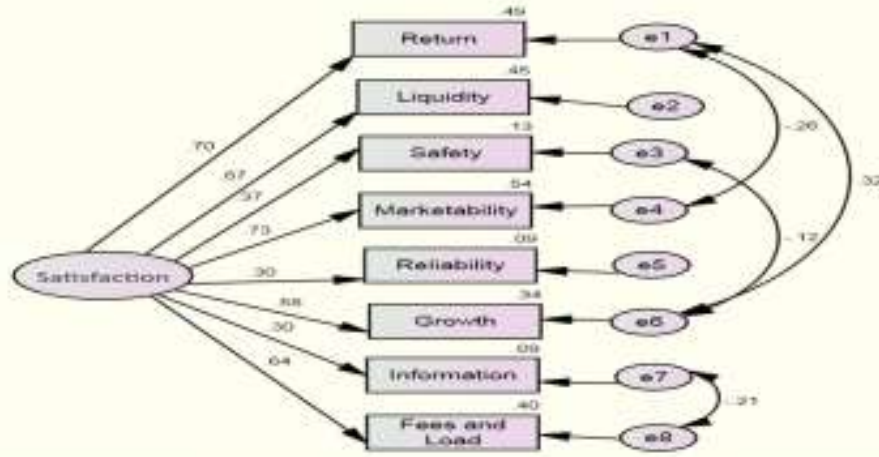

\section{Source: Primary Data}

The regression coefficient obtained in the CFA analysis along with the ranking of satisfactory variables is given in the following table.

Table 6 The Regression Coefficients showing Factors in Satisfaction Level

\begin{tabular}{|c|c|c|c|}
\hline $\begin{array}{c}\text { Dependent } \\
\text { Variable }\end{array}$ & $\begin{array}{c}\text { Independent } \\
\text { Variable }\end{array}$ & $\begin{array}{c}\text { Regression } \\
\text { Coefficient }\end{array}$ & Rank \\
\hline \multirow{4}{*}{} & Return & 0.702 & 2 \\
\cline { 2 - 4 } & Liquidity & 0.671 & 3 \\
\cline { 2 - 4 } & Safety & 0.365 & 6 \\
\cline { 2 - 4 } & Marketability & 0.733 & 1 \\
\cline { 2 - 4 } & Reliability & 0.303 & 7 \\
\cline { 2 - 4 } & Growth & 0.581 & 5 \\
\cline { 2 - 4 } & Information availability & 0.296 & 8 \\
\cline { 2 - 4 } & Fees and Load structure & 0.635 & 4 \\
\hline
\end{tabular}

Source: Primary Data

From the table (4.101) return with a regression coefficient the most important satisfying factor that an investor look forward is marketability (.733) followed by $\operatorname{return}(.702)$ and liquidity (.671). It is worth mentioning that, safety and reliability were the least ranked factors.

\section{6c. Risk Tolerance and Satisfaction level}

Table 7 Means - Level of Satisfaction with regard to Risk Tolerance of Mutual Fund Investors

\begin{tabular}{|c|c|c|c|}
\hline \multicolumn{4}{|c|}{ Level of Satisfaction } \\
\hline Risk Tolerance & Mean & $\begin{array}{c}\text { Std. } \\
\text { Deviation }\end{array}$ & N \\
\hline High risk tolerance & 25.6852 & 6.62147 & 108 \\
\hline $\begin{array}{c}\text { Moderate risk } \\
\text { tolerance }\end{array}$ & 27.6862 & 4.55066 & 188 \\
\hline Less risk tolerance & 26.7727 & 6.68769 & 176 \\
\hline Total & 26.8877 & 5.94901 & 472 \\
\hline
\end{tabular}

Source: Primary Data

The mean value is the highest for the moderate risk tolerance category which means that their level of satisfaction is higher when compared to other categories.

Ho: There is no significant difference among risk tolerance level of mutual fund investors and their satisfaction level.

Ha: There is significant difference among risk tolerance level of mutual fund investors and their satisfaction level. 
Table 8 Oneway ANOVA -Level of Satisfaction of Mutual Fund Investorswith regard to Risk Tolerance

\begin{tabular}{|c|c|c|c|c|c|}
\hline \multicolumn{7}{|c|}{ Level of Satisfaction } \\
\hline & $\begin{array}{c}\text { Sum of } \\
\text { Squares }\end{array}$ & df & $\begin{array}{c}\text { Mean } \\
\text { Square }\end{array}$ & F & Sig. \\
\hline $\begin{array}{c}\text { Between } \\
\text { Groups }\end{array}$ & 278.359 & 2 & 139.180 & 3.982 & .019 \\
\hline $\begin{array}{c}\text { Within } \\
\text { Groups }\end{array}$ & 16390.689 & 469 & 34.948 & & \\
\hline Total & 16669.049 & 471 & & & \\
\hline
\end{tabular}

Source: Primary Data

From the table (4.103) the p values were found to be lesser than 0.05 , for risk tolerance in the case of level of satisfaction of mutual fund investors and hence Ho is rejected stating that there is relationship between risk tolerance and satisfaction level of mutual fund investors. Since the ANOVA is found to be significant, Tukeys multiple comparison test was conducted to identify which group of risk investors have significant difference.

Table 9 Significance of Mean Difference in Level of Satisfaction based on Risk Tolerance - Post Hoc

\begin{tabular}{|c|c|c|c|c|c|c|}
\hline \multicolumn{7}{|c|}{ Dependent Variable: Level of Satisfaction LSD } \\
\hline \multirow{2}{*}{$(\mathrm{I})$} & $(\mathrm{J})$ & $\begin{array}{c}\text { Mean } \\
\text { Difference } \\
\text { (I-J) }\end{array}$ & $\begin{array}{c}\text { Std. } \\
\text { Error }\end{array}$ & Sig. & \multicolumn{2}{|c|}{$\begin{array}{c}\text { In\% Confidence } \\
\text { Interval }\end{array}$} \\
\cline { 5 - 8 } & $\begin{array}{c}\text { Lower } \\
\text { Bound }\end{array}$ & $\begin{array}{c}\text { Upper } \\
\text { Bound }\end{array}$ \\
\hline $\begin{array}{c}\text { High risk } \\
\text { tolerance }\end{array}$ & $\begin{array}{c}\text { Moderate } \\
\text { isk tolerance }\end{array}$ & $-2.00099^{*}$ & .71378 & .005 & -3.4036 & -.5984 \\
\cline { 2 - 7 } & $\begin{array}{c}\text { Less risk } \\
\text { tolerance }\end{array}$ & -1.08754 & .72261 & .133 & -2.5075 & .3324 \\
\hline $\begin{array}{c}\text { Moderate } \\
\text { risk } \\
\text { tolerance }\end{array}$ & $\begin{array}{c}\text { Less risk } \\
\text { tolerance }\end{array}$ & .91344 & .62005 & .141 & -.3050 & 2.1319 \\
\hline
\end{tabular}

Source: Primary Data Significant at the 0.05 levels

The Post Hoc analysis reveals the significance of means difference between risk tolerances with respect to satisfaction level of investors. The result shows that in the case of satisfaction level, the respondents in the high risk category significantly differ from the respondents of moderate risk category.

\section{FINDINGS}

\section{Risk Tolerance and Satisfaction Level of Mutual Fund Retail Investors:}

i. Of the total respondents $21.19 \%$ of mutual fund investors have high risk tolerance and $44.07 \%$ had moderate risk tolerance.

ii. There is association between the demographic variables age and risk tolerance level.

iii. Of the total respondents, $82 \%$ were moderately satisfied with mutual fund as an investment source.

iv. There is association between age and zone with regard to the satisfaction of mutual fund investors.

v. The most important satisfying factor that an investor look forward is marketability (.733) followed by return
(.702) and liquidity (.671). It is worth mentioning that, safety and reliability were the least ranked factors.

vi. The mean value is the highest for the moderate risk tolerance category which means that, their level of satisfaction is higher when compared to other categories.

vii. There is significant difference among risk tolerance level of mutual fund investors and their satisfaction level and the respondents in the high risk category significantly differ from the respondents of moderate risk category.

viii. The Post Hoc analysis reveals the significance of means difference between risk tolerances with respect to satisfaction level of investors. The result shows that in the case of satisfaction level, the respondents in the high risk category significantly differ from the respondents of moderate risk category.

\section{CONCLUSION}

The study was undertaken with the primary objective to understand the risk tolerance level and satisfaction level of mutual fund investors. Investors with moderate risk tolerance level prefer to invest in mutual funds and return, marketability and liquidity were the most satisfying factors investor looks into. To attract retail investors, a stable longterm performance by funds is most desirable. Asset management companies with a good track record over a period of time will be successful in drawing more funds from investors. Mutual funds need to be positioned appropriately as a long term product in the investor's mind. Distributors hence need to be incentivised adequately in order to sell the product correctly to investor's.

The mutual fund industry is evolving continuously through effectively managing investments and designing long term strategy for targeting and retaining customers. It has to develop products to fulfil customer's needs and help them to understand how its products cater to their needs. The long term strategy will need to supplement with innovative strategies in distribution, product innovation and creating customer awareness. The mutual fund industry manifests huge opportunity for growth and further penetration, with technological support. The key lies in strengthening distribution networks and enhancing levels of investor education to increase presence in rural areas. Efforts should be made jointly by regulatory bodies, AMCs and distributors to instil confidence in the minds of the investor and to encourage them to invest in mutual funds, even in times of uncertainty.

\section{REFERENCES}

[1] Lowenstein, G.H., Hsee, C.K, Weber, E.U. \& Welch, N. (2001). Risk as feelings. Psychological Bulletin, 127(2):267-286. 
[2] Byrnes, J . P., Miller, D. C. \& Schafer, W. D. (1999). Gender differences in risk taking: A meta-analysis. Psychological Bulletin, 125 (3) 367 383.

[3] Jaggia, S. \& Thosar, S. (2000). Risk aversion and the investment horizon: A new perspective on the time diversification debate. The Journal of Psychology and Financial Markets, 1, 211-215.

[4] Wallach, M. A. \& Kogan, N. (1961). Aspects of judgment and decision making: Interrelationships and changes with age. Behavioral Science, 6, 23- 26.

[5] Slovic, P. (1966). Risk-taking in children: Age and sex differences child development, 37, 169-176.

[6] Baker, H. K., \& Haslem, J. A. (1974). The impact of investor socioeconomic characteristics on risk and return preferences. Journal of Business Research, 2, 469-476.

[7] Cohn, Richard A., W. G. Lewellen, R.C Lease \& G. G Schlarbaum. (1975) Individual investor risk aversion and investment portfolio composition. Journal of Finance, 30(2), 605-620.

[8] Friend, I., \& Blume, M. (1975). The demand for risky assets. American Economic Review, 65, 900-922.

[9] Morin, R., \& Suarez, F. (1983). Risk aversion revisited. Journal of Finance, 38, 1201-1216.

[10] Bellante, D., \& Saba, R. (1986). Human capital and life-cycle effects on risk aversion. Journal of Financial Research, 9, 41-51.

[11] Siegel, F., \& Hoban, J., Jr. (1991). Measuring risk aversion: Allocation, leverage, and accumulation. Journal of Financial Research, 14, $27-35$.

[12] Riley, W. Jr., \& Chow, K. (1992). Asset allocation and individual risk aversion. Financial Analysts Journal, 48, 32-37.

[13] LeBaron, D., Farrelly, G., \& Guha, S. (1989). Facilitating a dialogue on risk: A questionnaire approach. Financial Analysts Journal, 45, 19-24.

[14] Schooley, D., \& Worden, D. (1996). Risk aversion measures: Comparing attitudes and asset allocation. Financial Services Review, 5, 87-99.

[15] Lipe, M. G., (1998). Individual investors' risk judgments and investment decisions: the impact of accounting and market data, Accounting Organizations and Society 23, 625-640.

[16] Yang, J. \& Qiu, W. (2005). A measure of risk and a decision-making model based on expected utility and entropy, European Journal of Operational Research, 164, 792-799.

[17] Viscusi, W. K. (1992). Fatal Tradeoffs: Public and private responsibilities for risk.New York: Oxford University Press.

[18] Horvath, P., \& Zuckerman, M. (1993). Sensation seeking, risk appraisa and risky behaviour. Personality and Individual Differences, 14, 41-52.

[19] Roszkowski, M. J., Snelbecker, G. E., \& Leimberg, S. R. (1993). Risktolerance and risk aversion. The tools and techniques of financial planning. (4th ed., pp. 213-225). Cincinnati, OH: National Underwriter.

[20] Yoo, Peter S. (1994). Age dependent portfolio selection. Working Paper 1994-003A, Federal Reserve Bank of St. Louis.

[21] Mittra, S. (1995). Practicing financial planning: A complete guide for professionals. Michigan: Mittra \& Associates.

[22] Haliassos, M., \& Bertaut, C. C. (1995). Why do so few hold stocks? The Economic Journal, 105, 1110-1129.

[23] Sung, J., \& Hanna, S. (1996a). Factors related to household risk-tolerance: An ordered probability analysis. Consumer Interests Annиal, 42, 227-228.

[24] Sung, J., \& Hanna, S. (1996b). Factors related to risk-tolerance. Financial counselling and planning, 7, 11-20.

[25] Malkiel, B. G. (1996). A random walk down Wall Street. New York: W. W.Norton \& Co.

[26] Canner, N., Mankiw, N. G., \& Weil, D. (1997). An asset allocation puzzle. American Economic Review, 87, 181-191.

[27] John E. Grable, (1997). Investor risk tolerance: Testing of demographics as the efficacy differentiating and classifying factors, Dissertation submitted to the Faculty of the Virginia Polytechnic Institute and State University, October 20.
[28] Olsen, R.A. (1998). Behavioral finance and its implications for stockprice volatility. Financial Analysts Journal, 54, 10-18.

[29] Byrnes, J . P., Miller, D. C. \& Schafer, W. D. (1999). Op. cit.

[30] Bajtelsmit, V. L., \& Bernasek, A. \& Jianakoplos, N. A. (1999). Gender differences in defined contribution pension decisions. Financial Services Review, 8(1), 1-10.

[31] Govind Hariharan, Kenneth S. Chapman, \& Dale L. Domian, (2000). Risk tolerance and asset allocation for investors nearing retirement. Financial Services Review 9 159-170

[32] Jaggia, S. \& Thosar, S. (2000). Op. cit.

[33] Barber, B. M. \& Odean, T. (2001). Boys will be boys: Gender, overconfidence, and common stock investment. The Quarterly Journal of Economics, 116, $261-288$.

[34] Dwyer, P. D., Gilkeson, J. H. and List, J. A. (2002). Gender differences in revealed risk taking: Evidence from mutual fund investors, Economic Letters, Vol. 76, pp. $151-158$

[35] Dulebohn James H (2002). An investigation of the determinants of investment risk behavioural in employer sponsored retirements plan. Journal of Management, 28(1) 3-26.

[36] Kenneth A. Froot, Paul G. J.\& O'Connell.(2003). The Risk tolerance of international investors, Working Paper 10157, Bureau of Economic Research.

[37] Rajarajan.V (1997). Investment size based segmentation of individual investors. Management Researcher, 3(3 \& 4), 27-36.

[38] Rajarajan.V (1998). Stages in life cycle and investment pattern. The Indian Journal of Commerce, 51(2 \& 3), 27-36.

[39] Rajarajan.V (2000). Investors' lifestyles and investment characteristics. Finance India, 14( 2), 465-478.

[40] Rajarajan.V (2003). Investors' demographics and risk bearing capacity. Finance India, 17(2), 565-576.

[41] Frieder, L, (2004). An investigation of the trading patterns and heuristics of stockholders, University of California, Los Angeles.

[42] Statman, M, Thorley, S., \& Vorkink, K., (2006) Investors overconfidence and trading volume. Journal of Economics, 116 261-292

[43] Glaser, M. and M. Weber (2007). Overconfidence and trading volume, Geneva Risk Insurance Review 32, pp1-36.

[44] Jasim Y. Al-Ajmi (2008). Risk tolerance of individual investors in an emerging market. International Research Journal of Finance and Economics, Issue 17

[45] Prabakaran G \& Jayabal G (2009). Investors risk tolerance towards mutual fund investments. Southern Economist, 15, 27-30.

[46] Syed Tabassum Sultana (2010). An empirical study of Indian individual investors' behavior, Global Journal of Finance and Management, 2 (1), pp. 19-33.

[47] Rui Yaoa, Deanna L. Sharpe, Feifei Wangc (2011). Decomposing the age effect on risk tolerance, The Journal of Socio-Economics, 40, 879-887.

[48] Ebrahim Kunju Sulaiman (2012). An empirical analysis of financial risk tolerance and demographic features of individual investors, Procedia Economics and Finance Volume 2, Pages 109-115.

[49] Rahmawati, M. Dileep Kumar, Meyland Kambuaya, Farhan Jamil, Saqib Muneer,(2015) "Determinants of the Risk Tolerance of Individual Investors", International Journal of Economics and Financial Issues, Vol 5, Special Issue ISSN: 2146-4138,2015.

[50] Sandip Chattopadhyay, Ranjan Dasgupta, (2015)“'Demographic and Socioeconomic Impact on Risk Attitudes of The Indian Investors - An Empirical Study", Asian Economic and financial Review, Volume 05; Number 04, Pg. 601- 623

[51] Kavita Chavali1, M. Prasanna Mohanraj, (2016)“Impact of Demographic Variables and Risk Tolerance on Investment Decisions: An Empirical Analysis", International Journal of Economics and Financial Issues, Vol. 6 (1), Pg. 169- 175, ISSN: 2146-4138, 2016 